\title{
Preface: OzFlux: a network for the study of ecosystem carbon and water dynamics across Australia and New Zealand
}

\author{
Eva van Gorsel ${ }^{1}$, James Cleverly ${ }^{2}$, Jason Beringer ${ }^{3}$, Helen Cleugh $^{4}$, Derek Eamus $^{2}$, Lindsay B. Hutley ${ }^{5}$, Peter Isaac ${ }^{6}$, \\ and Suzanne Prober ${ }^{7}$ \\ ${ }^{1}$ Fenner School of Environment and Society, The Australian National University, ACT, Canberra, Australia \\ ${ }^{2}$ School of Life Sciences, University of Technology Sydney, Broadway, NSW, 2007, Australia \\ ${ }^{3}$ The UWA School of Agriculture and Environment, The University of Western Australia, Crawley, WA, 6020, Australia \\ ${ }^{4}$ CSIRO Climate Science Centre, Canberra, 2601, Australia \\ ${ }^{5}$ Research Institute for the Environment and Livelihoods, Charles Darwin University, Darwin, NT 0909 Australia \\ ${ }^{6}$ OzFlux, Melbourne, VIC 3159, Australia \\ ${ }^{7}$ CSIRO Land and Water, Floreat, 6913, Australia
}

Correspondence: Eva van Gorsel (eva.vangorsel@anu.edu.au)

Published: 16 January 2018

This special issue of Biogeosciences synthesises and interprets the research outputs and results from OzFlux, the Australian and New Zealand Flux Network. The OzFlux community dedicates this special issue to Dr Ray Leuning, who made profound and significant contributions to our knowledge of land-vegetation-atmosphere interactions and generously offered his thoughtful consideration to students and early career researchers globally. His dedication to teaching was expressed through direct interactions, as a regular lecturer in the flux course in the USA, and the annual data workshops that he originally organised for OzFlux and that continue in his honour. Ray personally visited many potential sites for the OzFlux network across Australia and New Zealand, where his insight ensured that best practice and fit-for-purpose measurement methods were used that were appropriate for each location's unique situation. Ray, with colleagues, founded OzFlux in 2001 (Beringer et al., 2016) and continued to guide OzFlux as it grew its depth of understanding and grew in size, scope and impact. Ray's vision of interdisciplinary science was realised when OzFlux was supported via the Australian government's National Collaborative Infrastructure Scheme's funding to the Terrestrial Ecosystem Research Network (TERN) in 2009.

Carbon is naturally circulated between the atmosphere, ocean and terrestrial biosphere on timescales ranging from sub-daily to millennia. Exchanges with geologic pools occur on even longer timescales. In addition to this natural carbon cycle, anthropogenic emissions occur predominantly through land-use change and fossil fuel emissions (Achard et al., 2014). The Earth's natural carbon sinks (oceans and terrestrial) continue to remove about half of the global emissions of carbon dioxide that are released via human activity into the atmosphere (Jones et al., 2016). As a result of these processes, atmospheric $\mathrm{CO}_{2}$ concentrations have increased from about $277 \mathrm{ppmv}$ in 1750 to $>400 \mathrm{ppmv}$ in November 2015 (Le Quéré et al., 2016, and citations therein). Terrestrial ecosystems have been taking up increasing amounts of $\mathrm{CO}_{2}$ albeit with a sink strength that varies greatly between years, especially in the semi-arid and savanna vegetation of Australia (Poulter et al., 2014; Trudinger et al., 2016). Likewise, dry temperate eucalypt forests can be a very large sink for carbon (Hinko-Najera et al., 2017; Leuning et al., 2005), although these highly productive ecosystems can become a carbon source due to the direct and indirect effects of climate variability (van Gorsel et al., 2013). Bristow et al. (2016) show in this special issue that clearing of woody vegetation from the tropical savanna results in carbon emissions double the size of that reported for savanna burning. Rainfall is an important driver of photosynthesis in Australian ecosystems, and fluctuations of rainfall and productivity in Australia have been associated with multiple climate indices (Cleverly et al., 2016; Rogers and Beringer, 2017). Australia's climate has always been characterised by extreme, high-impact weather events such as cyclones, storms, fire 
weather and heatwaves. The "Angry Summer" heatwave of 2012-2013 (Climate Council, 2014) reflected the resilience of Australian vegetation (Ma et al., 2016), although that resilience is being tested as longer droughts, more severe heatwaves and strengthened land-climate feedbacks increase in frequency and intensity due to climate change (van Gorsel et al., 2016). Like extreme weather, fire has a transformative impact on Australian ecosystems and the carbon cycle (Beringer et al., 2016; Whitley et al., 2017). The carbon cycle is intrinsically linked to the water cycle and no more so than in Australia, "a land of drought and flooding rains" (Dorothea Mackellar, http://www.dorotheamackellar. com.au/archive/mycountry.htm). The strong influence of water availability on net carbon fluxes in Australian landscapes provides an important constraint on plans to reduce Australia's greenhouse gas emissions using land management practices.

A more detailed understanding of the dynamic soil-plantatmosphere continuum is critical to explain and predict past and future trends and variability in the terrestrial carbon and water cycles, and this knowledge is required by resource managers and policymakers seeking to manage carbon and water resources. Differential allocation of resources (i.e. water, carbon, light) between roots and shoots by grasses compared to trees supports the hypothesis that tree cover in the Australian savanna is determined primarily by resource limitation (Haverd et al., 2016). Root water uptake is a key determinant of observed differences in the behaviour of $\mathrm{C}_{3}$ woody and $\mathrm{C}_{4}$ grass components of savanna ecosystems (Whitley et al., 2016). Contrasting patterns of root water uptake result in seasonal variations in phenology on canopy, understory and ecosystem scales, with consequential effects on photosynthetic production (Moore et al., 2016a; Whitley et al., 2017). Trees and grasses have been shown to have distinct light-use efficiencies, which affects photosynthesis and enables gross primary production (Moore et al., 2017) to be tracked and inferred from phenocam networks on the ground or from space for some ecosystems (Moore et al., 2016b). Restrepo-Coupe et al. (2016) showed in this special issue that satellite-based, remotely sensed data are more strongly related to the photosynthetic potential of ecosystems than to actual photosynthesis, and that these data can be used for large-scale estimation of photosynthetic production across the Australian continent.

Natural fluxes must be measured to better understand land-climate interactions, feedbacks and climate regulation. Flux networks are integrated through their common infrastructure and data (Isaac et al., 2017). Research advances by the OzFlux community have led to improved, processoriented application of gap-filling and partitioning of carbon fluxes between gross primary production and ecosystem respiration (Beringer et al., 2017; Isaac et al., 2017; McHugh et al., 2017). In this special issue, OzFlux has also contributed to our understanding of micrometeorological methods for measurements of trace gases (for example methane and $\mathrm{N}_{2} \mathrm{O}$ ) over grazed pasture in New Zealand (Laubach et al., 2016). Hunt et al. (2016) find that intensive pasture management with irrigation does not necessarily lead to carbon losses under the pasture; provided that the carbon in cattle excreta is returned to the pasture, even gains are possible. Soil in Australian temperate forests is a consistent sink for methane, showing little response to temperature and driven largely by variations in soil moisture content and, conversely, air-filled porosity (Fest et al., 2017). These studies are made possible by networks of flux towers using the eddy covariance method, contributing to an improved process-based understanding that is central to the building of models and their verification. Regional networks like OzFlux further contribute to integration of these data and findings across a global network, FLUXNET, which has operated since 1997 (Baldocchi et al., 2001) and continues at hundreds of research sites around the world.

This special issue reflects the breadth of scientific research to which Ray made significant contributions, including (i) methodological aspects of observations and their interpretation (Beringer et al., 2017; Isaac et al., 2017; McHugh et al., 2017); (ii) upscaling ecosystem-scale measurements to regional and larger scales using remote sensing and physical modelling (Haverd et al., 2016; Laubach et al., 2016; Moore et al., 2016b; Restrepo-Coupe et al., 2016; Trudinger et al., 2016; Whitley et al., 2016); and (iii) analysis of carbon, water and energy cycles in response to land use and climate change, extreme weather, and fire (Bristow et al., 2016; Hinko-Najera et al., 2017; Hunt et al., 2016; Moore et al., 2016a, 2017; van Gorsel et al., 2016; Fest et al., 2017). Ray's approach to science was to always capture process understanding and integrate this into models that could be used to deliver predictions and solutions. An in-depth overview of Ray's scientific achievements is given in Cleugh (2013). We remember him well for his quotes, often given with a sincerity that showed his unshakable moral centre: "Work not published is work not done" (we have a responsibility to give back to society); "Don't publish ephemera" (put forth your best effort to answer important questions); "What is your hypothesis?" (only when we are testing hypotheses are we engaging with the scientific method); "Know thy site" (go out there, experience, learn and understand how the ecosystem and the instrumentation work); "Health warning: this lecture contains equations" (because sometimes they are required for proper understanding); and "Beat the drum" and "Ring your bell" (let others know what important discoveries you have made).

Ray made an enormous contribution to science, and his research will have an enduring impact as evidenced by a large and increasing number of citations and the use of his work in textbooks. His work will also continue through the many colleagues, postdoctoral researchers and postgraduate students with whom he has generously shared his knowledge. Not only has he taught in many summer schools and courses around the world, but many of us experienced how Ray would simply take a day out of his very busy work life to discuss a scientific problem. He would give support all the 
way through, from rigorously answering the scientific question to publishing the answers in a peer-reviewed publication. Ray had an impeccably high standard that he also expected of the community and this has held the community in good stead through rigorous publications. He always insisted on getting the best value out of the science we did. Through his engagement, Ray has certainly helped the OzFlux community to go all the way from a loose collection of colleagues involved in flux work, through to the coordinated network that is OzFlux, which collects high-quality data that have been published in this special issue and as well numerous other publications. His legacy has ensured the future success of OzFlux.

One of Ray's favourite books was Of Men and Numbers: The Story of the Great Mathematicians (Muir, 1961). It includes Sir Isaac Newton's quote "If I have seen further, it is by standing on the shoulders of giants". Ray was a true intellectual giant to the OzFlux community and we would not have been able to make the contributions to FLUXNET and the wider scientific community if it were not for him. On 12 February 2018 it will be 2 years since Ray left us. He is sorely missed but we are deeply grateful for the contributions he has made to both the OzFlux and the wider scientific communities. We are grateful to Ray for his wonderful collegiality, his tremendous contributions to science and his willingness to share his great knowledge with all of us.

Stefan K. Arndt, Mila Bristow, David Campbell, Helen A. Cleugh, James Cleverly, Derek Eamus, Cacilia Ewenz, Benedikt J. Fest, Peter Grace, Anne Griebel, Samantha Grover, Vanessa Haverd, John Hunt, Nina HinkoNajera, Peter Isaac, Georgia Koerber, Johannes Laubach, Michael J. Liddell, Craig Macfarlane, Ian D. McHugh, Wayne Meyer, Caitlin E. Moore, Elise Pendall, Alison Phillips, Rebecca L. Phillips, Suzanne M. Prober, Natalia Restrepo-Coupe, Susanna Rutledge, Cassandra Rogers, Ivan Schroder, Richard Silberstein, Cathy M. Trudinger, Eva van Gorsel, Camilla Vote, Tim Wardlaw and Rhys Whitley.

\section{References}

Achard, F., Beuchle, R., Mayaux, P., Stibig, H.-J., Bodart, C., Brink, A., Carboni, S., Desclée, B., Donnay, R., Hugh D. E., Lupi, A., Ra, R., Seliger, R., and Simonetti, D.: Determination of tropical deforestation rates and related carbon losses from 1990 to 2010, Glob. Change Biol., 20, 2540-2554, https://doi.org/10.1111/gcb.12605, 2014.

Baldocchi, D. D., Falge, E., Gu, L., Olson, R., Hollinger, D., Running, S., Anthoni, P., Bernhofer, C., Davis, K., Evans, R., Fuentes, J., Goldstein, A., Katul, G., Law, B., Lee, X., Malhi, Y., Meyers, T., Munger, W., Oechel, W., Paw, K. T. U., Pilegaard, K., Schmid, H. P., Valentini, R., Verma, S., Vesala, T., Wilson, K., and Wofsy, S.: FLUXNET?: A New Tool to Study the Temporal and Spatial Variability of Ecosystem-Scale Carbon Dioxide, Water Vapor, and Energy Flux Densities, B. Am.
Meteorol. Soc., 82, 2415-2434, https://doi.org/10.1175/15200477(2001)082<2415:FANTTS>2.3.CO;2, 2001.

Beringer, J., Hutley, L. B., McHugh, I., Arndt, S. K., Campbell, D., Cleugh, H. A., Cleverly, J., Resco de Dios, V., Eamus, D., Evans, B., Ewenz, C., Grace, P., Griebel, A., Haverd, V., HinkoNajera, N., Huete, A., Isaac, P., Kanniah, K., Leuning, R., Liddell, M. J., Macfarlane, C., Meyer, W., Moore, C., Pendall, E., Phillips, A., Phillips, R. L., Prober, S. M., Restrepo-Coupe, N., Rutledge, S., Schroder, I., Silberstein, R., Southall, P., Yee, M. S., Tapper, N. J., van Gorsel, E., Vote, C., Walker, J., and Wardlaw, T.: An introduction to the Australian and New Zealand flux tower network - OzFlux, Biogeosciences, 13, 5895-5916, https://doi.org/10.5194/bg-13-5895-2016, 2016.

Beringer, J., McHugh, I., Hutley, L. B., Isaac, P., and Kljun, N.: Technical note: Dynamic INtegrated Gap-filling and partitioning for OzFlux (DINGO), Biogeosciences, 14, 1457-1460, https://doi.org/10.5194/bg-14-1457-2017, 2017.

Bristow, M., Hutley, L. B., Beringer, J., Livesley, S. J., Edwards, A. C., and Arndt, S. K.: Quantifying the relative importance of greenhouse gas emissions from current and future savanna land use change across northern Australia, Biogeosciences, 13, 62856303, https://doi.org/10.5194/bg-13-6285-2016, 2016.

Cleugh, H.: Preface for the special issue on water and carbon coupling to honour Dr Ray Leuning, Agr. Forest Meteorol., 182183, 189-190, https://doi.org/10.1016/j.agrformet.2013.08.009, 2013.

Cleverly, J., Eamus, D., Luo, Q., Restrepo Coupe, N., Kljun, N., Ma, X., Ewenz, C., Li, L., Yu, Q., and Huete, A.: The importance of interacting climate modes on Australia's contribution to global carbon cycle extremes, Sci. Rep.-UK, 6, 23113, https://doi.org/10.1038/srep23113, 2016.

Climate Council: Angry Summer 2013/2014, available at: http: //www.climatecouncil.org.au/angry-summer (last access: 1 October 2016), 2014.

Fest, B. J., Hinko-Najera, N., Wardlaw, T., Griffith, D. W. T., Livesley, S. J., and Arndt, S. K.: Soil methane oxidation in both dry and wet temperate eucalypt forests shows a near-identical relationship with soil air-filled porosity, Biogeosciences, 14, 467479, https://doi.org/10.5194/bg-14-467-2017, 2017.

Haverd, V., Smith, B., Raupach, M., Briggs, P., Nieradzik, L., Beringer, J., Hutley, L., Trudinger, C. M., and Cleverly, J.: Coupling carbon allocation with leaf and root phenology predicts tree-grass partitioning along a savanna rainfall gradient, Biogeosciences, 13, 761-779, https://doi.org/10.5194/bg-13-761-2016, 2016.

Hinko-Najera, N., Isaac, P., Beringer, J., van Gorsel, E., Ewenz, C., McHugh, I., Exbrayat, J.-F., Livesley, S. J., and Arndt, S. K.: Net ecosystem carbon exchange of a dry temperate eucalypt forest, Biogeosciences, 14, 3781-3800, https://doi.org/10.5194/bg-143781-2017, 2017.

Hunt, J. E., Laubach, J., Barthel, M., Fraser, A., and Phillips, R. L.: Carbon budgets for an irrigated intensively grazed dairy pasture and an unirrigated winter-grazed pasture, Biogeosciences, 13, 2927-2944, https://doi.org/10.5194/bg-13-2927-2016, 2016.

Isaac, P., Cleverly, J., McHugh, I., van Gorsel, E., Ewenz, C., and Beringer, J.: OzFlux data: network integration from collection to curation, Biogeosciences, 14, 2903-2928, https://doi.org/10.5194/bg-14-2903-2017, 2017. 
Jones, C. D., Ciais, P., Davis, S. J., Friedlingstein, P., Gasser, T., Peters, G. P., Rogelj, J., van Vuuren, D. P., Canadell, J., G., Cowie, A., Jackson, R. B., Jonas, M., Kriegler, E., Littleton, E., Lowe, J. A., Milne, J., Shrestha, G., Smith, P., Torvanger, A., and Wiltshire A.: Simulating the Earth system response to negative emissions, Environ. Res. Lett., 11, 095012, https://doi.org/10.1088/1748-9326/11/9/095012, 2016.

Laubach, J., Barthel, M., Fraser, A., Hunt, J. E., and Griffith, D. W. T.: Combining two complementary micrometeorological methods to measure $\mathrm{CH}_{4}$ and $\mathrm{N}_{2} \mathrm{O}$ fluxes over pasture, Biogeosciences, 13, 1309-1327, https://doi.org/10.5194/bg-131309-2016, 2016.

Le Quéré, C., Andrew, R. M., Canadell, J. G., Sitch, S., Korsbakken, J. I., Peters, G. P., Manning, A. C., Boden, T. A., Tans, P. P., Houghton, R. A., Keeling, R. F., Alin, S., Andrews, O. D., Anthoni, P., Barbero, L., Bopp, L., Chevallier, F., Chini, L. P., Ciais, P., Currie, K., Delire, C., Doney, S. C., Friedlingstein, P., Gkritzalis, T., Harris, I., Hauck, J., Haverd, V., Hoppema, M., Klein Goldewijk, K., Jain, A. K., Kato, E., Körtzinger, A., Landschützer, P., Lefèvre, N., Lenton, A., Lienert, S., Lombardozzi, D., Melton, J. R., Metzl, N., Millero, F., Monteiro, P. M. S., Munro, D. R., Nabel, J. E. M. S., Nakaoka, S.-I., O’Brien, K., Olsen, A., Omar, A. M., Ono, T., Pierrot, D., Poulter, B., Rödenbeck, C., Salisbury, J., Schuster, U., Schwinger, J., Séférian, R., Skjelvan, I., Stocker, B. D., Sutton, A. J., Takahashi, T., Tian, H., Tilbrook, B., van der Laan-Luijkx, I. T., van der Werf, G. R., Viovy, N., Walker, A. P., Wiltshire, A. J., and Zaehle, S.: Global Carbon Budget 2016, Earth Syst. Sci. Data, 8, 605-649, https://doi.org/10.5194/essd-8-605-2016, 2016.

Leuning, R., Cleugh, H. A., Zegelin, S. J., and Hughes, D.: Carbon and water fluxes over a temperate Eucalyptus forest and a tropical wet/dry savanna in Australia: measurements and comparison with MODIS remote sensing estimates, Agr. Forest Meteorol., 129, 151-173, https://doi.org/10.1016/j.agrformet.2004.12.004, 2005.

Ma, X., Huete, A., Cleverly, J., Eamus, D., Chevallier, F., Joiner, J., Poulter, B., Zhang, Y., Guanter, L., Meyer, W., Xie, Z., and Ponce-Campos, G.: Drought rapidly diminishes the large net $\mathrm{CO}_{2}$ uptake in 2011 over semi-arid Australia, Sci. Rep.-UK, 6, 37747, https://doi.org/10.1038/srep37747, 2016.

McHugh, I. D., Beringer, J., Cunningham, S. C., Baker, P. J., Cavagnaro, T. R., Mac Nally, R., and Thompson, R. M.: Interactions between nocturnal turbulent flux, storage and advection at an "ideal" eucalypt woodland site, Biogeosciences, 14, 3027-3050, https://doi.org/10.5194/bg-14-3027-2017, 2017.

Moore, C. E., Beringer, J., Evans, B., Hutley, L. B., McHugh, I., and Tapper, N. J.: The contribution of trees and grasses to productivity of an Australian tropical savanna, Biogeosciences, 13, 2387-2403, https://doi.org/10.5194/bg-13-2387-2016, 2016 a.

Moore, C. E., Brown, T., Keenan, T. F., Duursma, R. A., van Dijk, A. I. J. M., Beringer, J., Culvenor, D., Evans, B., Huete, A., Hutley, L. B., Maier, S., Restrepo-Coupe, N., Sonnentag, O., Specht, A., Taylor, J. R., van Gorsel, E., and Liddell, M. J.: Reviews and syntheses: Australian vegetation phenology: new insights from satellite remote sensing and digital repeat photography, Biogeosciences, 13, 5085-5102, https://doi.org/10.5194/bg13-5085-2016, 2016 b.
Moore, C. E., Beringer, J., Evans, B., Hutley, L. B., and Tapper, N. J.: Tree-grass phenology information improves light use efficiency modelling of gross primary productivity for an Australian tropical savanna, Biogeosciences, 14, 111-129, https://doi.org/10.5194/bg-14-111-2017, 2017.

Muir, J.: Of Men and Numbers: The Story of Great Mathematicians, Dodd, Mead \& Company, New York, USA, 1961.

Poulter, B., Frank, D., Ciais, P., Myneni, R. B., Andela, N., Bi, J., Broquet, G., Canadell, J. G., Chevallier, F., Liu, Y. Y., Running, S. W., Sitch, S., and van der Werf, G. R.: Contribution of semiarid ecosystems to interannual variability of the global carbon cycle, Nature, 509, 600-603, https://doi.org/10.1038/nature13376, 2014.

Restrepo-Coupe, N., Huete, A., Davies, K., Cleverly, J., Beringer, J., Eamus, D., van Gorsel, E., Hutley, L. B., and Meyer, W. S.: MODIS vegetation products as proxies of photosynthetic potential along a gradient of meteorologically and biologically driven ecosystem productivity, Biogeosciences, 13, 5587-5608, https://doi.org/10.5194/bg-13-5587-2016, 2016.

Rogers, C. D. W. and Beringer, J.: Describing rainfall in northern Australia using multiple climate indices, Biogeosciences, 14, 597-615, https://doi.org/10.5194/bg-14-597-2017, 2017.

Trudinger, C. M., Haverd, V., Briggs, P. R., and Canadell, J. G.: Interannual variability in Australia's terrestrial carbon cycle constrained by multiple observation types, Biogeosciences, 13, 6363-6383, https://doi.org/10.5194/bg-13-6363-2016, 2016.

van Gorsel, E., Berni, J., Briggs, P., Cabello-Leblic, A., Chasmer, L., Cleugh, H., Hacker, J., Hanson, S., Haverd, Hughes, D., Hopkinson, C., Keith, H., Kljun, N., Leuning, R., Yebra, M., and Zegelin, S.: Primary and secondary effects of climate variability on net ecosystem exchange in an evergreen Eucalyptus forest, Agr. Forest Meteorol., 182-183, 248-256, https://doi.org/10.1016/j.agrformet.2013.04.027, 2013.

van Gorsel, E., Wolf, S., Cleverly, J., Isaac, P., Haverd, V., Ewenz, C., Arndt, S., Beringer, J., Resco de Dios, V., Evans, B. J., Griebel, A., Hutley, L. B., Keenan, T., Kljun, N., Macfarlane, C., Meyer, W. S., McHugh, I., Pendall, E., Prober, S. M., and Silberstein, R.: Carbon uptake and water use in woodlands and forests in southern Australia during an extreme heat wave event in the “Angry Summer" of 2012/2013, Biogeosciences, 13, 5947-5964, https://doi.org/10.5194/bg-13-5947-2016, 2016.

Whitley, R., Beringer, J., Hutley, L. B., Abramowitz, G., De Kauwe, M. G., Duursma, R., Evans, B., Haverd, V., Li, L., Ryu, Y., Smith, B., Wang, Y.-P., Williams, M., and Yu, Q.: A model inter-comparison study to examine limiting factors in modelling Australian tropical savannas, Biogeosciences, 13, 3245-3265, https://doi.org/10.5194/bg-13-3245-2016, 2016.

Whitley, R., Beringer, J., Hutley, L. B., Abramowitz, G., De Kauwe, M. G., Evans, B., Haverd, V., Li, L., Moore, C., Ryu, Y., Scheiter, S., Schymanski, S. J., Smith, B., Wang, Y.-P., Williams, M., and $\mathrm{Yu}, \mathrm{Q} .:$ Challenges and opportunities in land surface modelling of savanna ecosystems, Biogeosciences, 14, 4711-4732, https://doi.org/10.5194/bg-14-4711-2017, 2017. 